\title{
The Art of Self-Making: Identity and Citizenship Education in Late- Modernity
}

\begin{abstract}
Taking the English National Curriculum as its main example, this paper argues that an overly nationalistic, normative and 'fact-based' Citizenship Education curriculum is failing to engage the dimensions of young people's identities which they experience as deeply meaningful. There is thus a chasm - albeit a false one - between official discourses and pedagogies of citizenship and what young people consider to be their 'real' selves. I argue that citizenship education must develop a more sophisticated understanding of the complexities of how identities are formed and performed, especially in light of globalisation and increasing migration. I also make a somewhat unorthodox argument for conceptualising 'relating-to-otherness' in the same way that we think of music consumption. This has implications for how we experience, interpret, value and create 'others'. The paper also makes some recommendations for how these ideas can begin to be implemented educational settings.
\end{abstract}

Key words: Citizenship education; self-making; performativity; consumption; identity; global citizenship

\section{Introduction}

Perhaps unsurprisingly - given political and economic challenges in the West and around the globe - questions of citizenship are today receiving an unprecedented amount of attention in academic, political and other quarters. This, no doubt, is related to the fact that ideas of citizenship are inextricably intertwined with how individuals define, experience and live notions of self, other, community, heritage, loyalty, and so forth. But it is also because 'citizenship' as a modern socio-legal category is undergoing rapid and quite unpredictable changes at global, national and local levels.

Globally, the dynamics of globalisation, which have in the past few decades been driven by a logic of 'flexible accumulation', have led especially in developed/Western countries to increased local demographic diversity whilst encouraging what has been referred to as 'flexible citizenship' - an individualistic approach whereby people move around the 
globe according to socio-economic opportunities (see Ong 1999; Hall 1992). In turn, these shifts have produced changes in local and national approaches to citizenship, leading them to become ever more varied and contradictory. Looking at the Netherlands, for example, Schinkel (2010) has distinguished between 'formal' and 'moral' citizenship in line with state neo-liberalism. This lends credence to Carens' (1987) argument that there are similarities between contemporary Western citizenship and the feudal system, in the sense that it is an inherited status which significantly enhances life chances and experiences. Similarly, we can point to recent debates surrounding 'the need' in some parts of the EU to control migration from Eastern Europe (which contradicts the EU's commitment to the Directive of Freedom of Movement). Whilst Giorgio Agamben's (1998) by now famous argument states that deprived of citizenship a person becomes reduced to 'bare life', it can be argued that today Eastern Europeans are having their social rights challenged despite being EU citizens. Finally, recent events such as the tragic killing of British soldier Lee Rigby in Woolwich, east London, bring to the surface local tensions surrounding issues of belonging, loyalty, 'us', 'them' and so on.

Following on from these issues, it almost goes without saying that around the world 'citizenship' has come to occupy an important place in educational curricula, particularly in secondary schooling. ${ }^{1}$ In England, 'citizenship' became a statutory part of the National Curriculum in September 2002. This move was arguably related to the Labour government's discourse and policies of 'community cohesion' introduced in the wake of the riots in the north of England in 2001 (which the Cantle Report blamed on ethnic minorities' 'selfsegregation') as well as the events of $9 / 11$ in the US. In the main, the idea is to instil in young people certain civic values and skills vis-á-vis loyalty, participation, conviviality and responsibility primarily at the level of the national community. This commitment to nation and state is by no means unique to England: despite acknowledging the challenges of globalisation, i.e. that key socio-economic problems are today global in nature, and despite encouragement for the development in young people of a 'global outlook', national governments continue to place a normative emphasis upon the national dimension of citizenship. However, as I discuss below, there is plenty of evidence to show that the nationalistic approach to citizenship education is far from adequate and is leaving many young people with a sense of indifference and disillusionment rather than a commitment to conviviality.

\footnotetext{
${ }^{1}$ See Department for Education 2011b.
} 
Within this context, I am firmly of the view that questions of citizenship education not only need attention but innovation. I also believe, in line with recent literature, that any innovative practice must account for all the dimensions of citizenship (including global, national, local and personal) and not favour one over another. Based on my recent research, I argue here that the socio-political facets of citizenship must be seen as part of a set of iterative processes which are intimately linked with the complexities of how selves are formed and performed in the late-modern world. This entails paying close attention especially to the migratory flows which are a key characteristic of today's globalised world, whilst focusing on the unique ways in which multiple times and spaces work in/through the diverse selves of contemporary citizens. It also involves reconceptualising how we think of interacting with or relating to others by accounting more readily for individual power and complicity in the creation and valuing of 'otherness'. In this vein, I draw on theory from the sociology of music to consider the possible relevance of aesthetic consumption and judgement for questions of selfhood and citizenship education. Thus, insofar as citizenship can be taught/learned, its teaching/learning must do more to acknowledge and account for the complex dimensions of identity and interaction whilst providing young people with sophisticated theoretical and reflexive tools for engaging with them. In this way, citizenship education can begin to engage young people much more immediately and meaningfully, allowing them to approach citizenship with more self-awareness, criticality and a sense of personal investment.

\section{Citizenship education in England}

Since 2002 all 11-16 year-olds in England have been taught 'citizenship' as a statutory part of their schooling. The government's decision to make citizenship a compulsory school subject was based on the Crick Report. Crick posited that citizenship education should be comprised of three strands: 1) social and moral responsibility; 2) community involvement; 3) political literacy. The aim, broadly, was to educate citizens who are self-confident, helpful, useful and morally responsible. Specifically, teaching should focus on four essential areas - i.e. 'concepts', 'values and dispositions', 'skills and aptitudes', 'knowledge and understanding' and ensure that pupils are well-versed in them. ${ }^{2}$ Despite its highly normative/proscriptive approach, the Crick report was committed to allowing schools a great deal of freedom in the design and delivery of citizenship lessons.

\footnotetext{
${ }^{2}$ Each of the four areas is broken down into more specific points. See Qualifications and Curriculum Authority 1998, 44.
} 
During his tenure as Secretary of State for Education (2010-2014), Michael Gove introduced a number of reforms to the National Curriculum including citizenship education. These reforms saw a 'slimming down' of the whole curriculum and were broadly in keeping with a Conservative ideology in that they championed a narrower, more nation-centric framework for citizenship. They also included something of a demotion in the status of citizenship education: having nearly been dropped altogether, the subject was eventually kept, though as a 'foundational' and not a 'core' subject. And given the Conservatives' huge support for academies, it can be argued that the subject is in danger of becoming marginalised as schools can choose to de-prioritise it.

Be that as it may, the National Curriculum lays out a broad framework for citizenship education. At Key Stage 3, for example: 'Teaching should ensure that knowledge and understanding about becoming informed citizens are acquired and applied when developing skills of enquiry and communication, and participation and responsible action'. ${ }^{3}$ For instance, it requires that pupils be taught about: legal and human rights and responsibilities underpinning society, basic aspects of the criminal justice system, and how both relate to young people; the diversity of national, regional, religious and ethnic identities in the United Kingdom and the need for mutual respect and understanding; central and local government, the public services they offer, how they are financed, and opportunities for contributing to them; the electoral system and the importance of voting; the work of community-based, national and international voluntary groups; the fair resolution of conflicts; the significance of the media; and the world as a global community including the political, economic, environmental and social implications of this, as well as the role of the European Union, the Commonwealth and the United Nations. At Key Stage 4, the areas covered are quite similar, but the skills-set has become more sophisticated to include independent research in citizenship-related issues. Similarly, at both Key Stages pupils are encouraged to think imaginatively about the experiences of others, and to reflect on social participation. However, we should interpret words such as 'independent research' and 'reflection' with some caution and suspicion given the highly 'fact based' nature of the curriculum: it is unlikely that pupils are given the tools to critically research 'citizenship' as much as they are invited to dig around in the 'facts' provided.

There is an interesting duality at play here. Seen from one perspective, the curriculum's 'broad framework' is actually not so broad at all. It provides an impressive

\footnotetext{
${ }^{3}$ Department for Education 2013.
} 
amount of statutory specificity as to the direction and content of teaching and learning. From another perspective, however, it is extremely vague. For instance, despite a clear emphasis upon learning about and valuing the UK's ethnic and religious diversity, as well as the issue of an increasingly globally interdependent world, the curriculum remains virtually silent on what sort of things 'diversity' actually entails (and why ethnic and religious diversity are singled out); how it is to be approached and engaged with; whether it has any relevance for interacting with others around the world; and what 'global citizenship' might look like more precisely. Presumably, this level of vagueness is to reduce the state's intervention and allow schools to be creative in their provision. However, there is evidence that these ambiguities framed within an otherwise normative curriculum are having negative effects. Since 2002 the government has commissioned various studies to gauge the impact of citizenship education. Two studies stand out in particular, and I will briefly discuss their findings in turn.

The first study was carried out by Maylor et al. in 2006. Looking at the whole National Curriculum, this research came to some important conclusions. Firstly, it showed that 'diversity' is all too often reduced to cultural and religious difference, thus excluding other forms of diversity such as social or white British diversity. It also referenced analyses of the Curriculum which have criticised it for being too Eurocentric and failing to value ethnic/religious diversity. Furthermore, it highlighted the problem that despite being allowed a great deal of professional flexibility, many teachers neither had adequate knowledge about diversity nor the training to teach its issues properly (Maylor et al. 2006, 81). This was compounded by the fact that for some schools, particularly those with low numbers of ethnicminority pupils, the teaching of issues of diversity was identified as a low priority and frequently ignored (ibid., 84). The study also showed that these problems were often related to particularly narrow understandings of national identity. Many schools seemed to be unaware of or unaffected by the wealth of academic literature which shows compellingly that identities are socially constructed and as such unstable, multiple and unfinished (cf. Hall 1991). In fact, in many schools, 'Britishness' was unproblematically equated with 'Englishness', whiteness and Christianity. By the same token, 'diversity' and 'difference' were almost invariably attributed to ethnic minorities by both teachers and pupils.

The detrimental implications of such an approach are clear: on the one hand, it allows for whiteness to disappear into the background as the norm; on the other hand, it leads to minority cultures and religions being reduced to a set of static ideal types which - as many pupils complained - is not representative of actual experiences (Maylor et al. 2006, 78). In this way, arguably, the UK's official approach to concepts such as self, other and belonging 
has not changed much since the assimilationist days of the 1950s. On a positive note, the study mentioned a generational shift in that today's pupils seem more open and tolerant to difference whilst displaying a negative stance towards racism. Maylor et al. thus recommended that pupils' own idealism be better harnessed when developing teaching materials. They also called for the National Curriculum to provide 'discursive resources' to enable a broadening of national identity which is inclusive of difference and allows for a retelling of national stories such that the contributions of minority groups are demonstrated (ibid., 111).

The second government commissioned study I want to discuss is the eighth and final report from the Citizenship Education Longitudinal Study (CELS) carried out by the National Foundation for Education Research (NFER) and published in 2010. This study examined the impact of the citizenship curriculum on young people and sought to shed light on a) how their citizenship practices changed over the course of the study (2002-2009), and b) what factors shape their citizenship outcomes. The key findings of NFER's study are: 1) young people's levels of civic and political participation have increased markedly. In contrast, 2) their attachment to notions of equality, society and community has weakened, and they tend to have less trust in politics. The corollary is that they tend to believe in their own individual benefit and well-being foremost. Finally, 3) young people increasingly associate being a good citizen with being law abiding. NFER's recommendation is to ensure that discrete citizenship lessons are planned and taught by citizenship education teachers and correspond to external examinations or certification. They also suggest that citizenship be embedded in the curriculum and extended through to the age of 18.

If I may impose my own - slightly cynical - interpretation on NFER's findings for a moment, it does seem that for some young citizens 'good citizenship' is seen as little more than a necessary headache to stay out of trouble with the authorities and the law so as to guarantee individual prosperity. This is clearly in contradiction to the (ostensible) ethos of the Crick Report and the National Curriculum. We might thus argue that the citizenship curriculum has done little to encourage a commitment to conviviality and to provide concrete strategies and skills for its realisation. Thus, 'others', of whom a given young person may only have superficial and stereotypical knowledge, are to be 'respected' (whatever that means) because failure to do so might have social and legal repercussions. There is, then, possibly a discrepancy between young people's 'official' attitudes towards citizenship and their everyday experience. 


\section{Some findings from my own research}

The issue of a discrepancy or discord between official attitudes and everyday/intimate experience - which some young people actually describe as a difference between an 'untrue' (but government-sanctioned) and a 'true' self - has been of interest to me in my own research for a few years now. Between 2012 and 2013, I conducted a research project ${ }^{4}$ to explore how young people approach these questions and what implications this might have for citizenship education. During the project, I interviewed fifteen young British citizens who had all received statutory citizenship education and were now undergraduates at UK universities. ${ }^{5}$ I also conducted a survey of 50 second-year undergraduates ${ }^{6}$ all of whom had received citizenship education in the UK, and did two focus groups in London, each with eight participants from a similar demographic group. Furthermore, I worked closely with a cultural organisation in London which champions the use of arts and artists in citizenship education and develops teaching materials in their artist-led 'immersive learning' initiatives for diverse children and young people from London.

The survey results warrant particular attention at this stage. Over sixty percent of respondents said that they had not learned anything useful in any of their citizenship lessons. The most common responses used to describe either what they remembered or how they felt were: 'nothing', 'I don't remember', 'irrelevant', 'useless', 'we didn't learn anything', and 'not sure'. The majority of the remaining respondents gave more positive but very vague responses such as: 'something about the EU', 'what the state expects of me', 'not to break the law' and 'stuff about sex and drug abuse'. Some respondents also commented on the teaching they received. Of these the vast majority (74\%) were strongly critical of what they broadly described as teachers' apathy and lack of knowledge. In subsequent focus groups, some commented that they felt citizenship education lessons were the 'not serious' lessons; the lessons to 'just stick a film on'. Of my survey respondents, only one actually praised her teacher for making her think about citizenship in a new way. These findings demonstrate that the statutory curriculum for citizenship education is largely unsuccessful in engaging and enthusing young people. Another interesting finding is that for many respondents 'citizenship' was felt to be inextricably linked to their identity and sense of self. One respondent even wrote: 'Citizenship is identity'. Others commented that whether or not they could be a 'good citizen' depended upon their ability/freedom to 'be themselves'; and some

\footnotetext{
${ }^{4}$ The project was partly funded by the AHRC

${ }^{5}$ Five were students at a Russell Group institution and ten at a post-92 university.

${ }^{6}$ The survey was done in the same post-92 UK institution that the interviewees studied at.
} 
suggested that Britain at present alienates certain young people, and this explains the attraction to extremist movements such as ISIS and the EDL.

As for the discrepancy between official or expected attitudes and 'true' selfexperience, this came up in a number of interviews as well. A key point which emerged was that young people are fully able to understand and articulate what they are being taught during citizenship lessons and how they are expected to behave; but these teachings rarely and inconsistently came to form a meaningful part of their day-to-day identities. The interview responses suggest that the many nuances of young people's identities, some of which are affective and non-verbal, all of which are deemed to be significant, are more or less untouched, unacknowledged, even dismissed by statutory citizenship education. For example, $\operatorname{Tim}^{7}, 22$, from Kent, said:

During the lesson, when the teacher asked us about respecting other people or whatever, we all knew that we had to answer something like: 'yeah, you shouldn't be racist, or, like, hurt people, or anything like that.' But as soon as the class finished, my friends would start shouting racist words and that sort of thing. We didn't really care, do you know what I mean? We just repeated what the teacher wanted to hear...

Another interviewee, Kelly, 19, said:

There are things which matter to me and my family - like our religion, for example...these things are not really properly talked about [in citizenship lessons], you know? And especially when it comes to religious people: everyone knows that most of the powerful classes think that religious people are deluded and shouldn't be taken seriously. And if it's Muslims, well then they might be terrorists or something. It's totally mad...Well, I'm a Christian; that's who I am, and that's how I deal with everything in my life.

Still another interviewee, Alina, 21, opined:

I'm British - like, completely. I was born here; I have the passport; English is my first language - everything. I have no problem with that and just think of myself as British. But the fact is that my parents migrated here from Turkey. So that's a part of my life too, you know? I speak Turkish sometimes. I know we're taught that as Brits we have to respect other cultures and nationalities. But for me that 'other part' is a part of my Britishness too. I don't feel that

\footnotetext{
${ }^{7}$ Pseudonyms used throughout.
} 
they taught that at school. The Turkish part of me was somehow always left out, or was, sort of, extra...

Statements such as these compel us to consider the complexities which arise when official discourses and pedagogies of citizenship interact with the manifold personal/social layers of individual identities. We should also take seriously the fact that despite all the talk of diversity, the official attitude towards citizenship and its teaching takes a definite position which otherises many British citizens - such as religious people and certain migrants. It is therefore important for all those interested in citizenship and citizenship education to 1) proceed from a critique hegemonic national(ist) ideologies and 2) to learn more about the individual and social processes and mechanisms through which young people approach, make acceptable or indeed reject official discourses and narratives of citizenship. These issues become all the more pertinent in the contemporary or late-modern world given the globe's increasing interconnectivity and the considerable, even unprecedented social, cultural, political and economic implications which unfold in its wake. In this vein, migration is particularly attention-worthy - i.e. not only that migration and displacement are increasingly taking centre stage in political and social debates, but also the fact that English classrooms are today super-diverse spaces which potentially encompass a wide range of migratory experiences and narratives. As such, they necessarily transcend the space-time of the nationstate (cf. Gilroy 1993) and complicate the experience of even those pupils and teachers who think of themselves as 'fully indigenous' to England (or 'truly/only British').

I will develop this argument below. For now, I must reiterate the point which others in the field (e.g. Osler 2015) have made in various guises: taking primarily a nationalistic approach to issues of citizenship and citizenship education will cause more problems than it solves - in fact, I think it is untenable. It will cause problems because irrespective of the rhetoric in which it is delivered, it always clearly defines 'us' and 'them' positions whilst demanding loyalty to a geo-political entity (the nation-state) whose very integrity is increasingly being fundamentally questioned at various levels. And it is untenable (and must be actively challenged) because there can be little hope that the myopic hegemony and powerful exclusivism of nationalist ideologies will ever change. Fernando's (2009) intriguing study of politically active French women from Muslim backgrounds shows that despite these women's total relinquishment of their religious and ethnic identities in favour of a secular French identity, and despite their willingness to adopt wholesale 'French citizenship' (which is what the state ostensibly desires of them), they are ultimately defined as 'other' and 
excluded from the 'full' experience of French citizenship. Fernando attributes this to the structures and machinations of French politics, which needs a visible and cultural other on whom it can blame the social problems that in reality the state is responsible for. I think there is strong evidence to suggest that the same can be said for British politics, including the fact that the government's flagship counter-radicalisation policy, PREVENT, describes violent extremism virtually entirely in relation to Islam and Muslims. 


\section{Citizenship beyond the nation-state?}

Talking of globalisation and migration and their destabilising of nationalistic models resulting in what some have described as a crisis of citizenship (see Castles and Davidson 2000; Banks 2004) - should not lead us to falsely assume that nation-states are mere spectators to their own downfall and can be written off. In many respects, nation-states, with all the resources at their disposal, remain powerful orchestrators of global affairs and of human experience at all levels (cf. Holton 2011). And so it is not surprising, as we saw above in the case of English Curriculum, that they have mounted their own response to the 'crisis' of national citizenship by acknowledging the transformative force of globalisation and emphasising the importance of education. In state schools around the world today, including in England, citizenship is generally understood as 'a system of values, efforts and institutionalised practices required for creating and maintaining conditions for living together in a complex society' (Dimitrov and Boyadjieva 2009, 156). It further denotes a membership which is marked by a set of common rights and duties which determine the extent of participation in national affairs (ibid.). Citizenship education, then, refers to a sort of political socialisation which promotes these rights and duties, as well as notions of heritage and collective identity. Thus, the aim of citizenship education is to provide students with certain civic knowledge and skills whilst emphasising the state's sovereignty and legitimacy, as well as citizens' rights, responsibilities and membership within national borders. In this narrative, then, although the usefulness of a 'global outlook' is championed, it is the national citizen who continues to take primacy as the site for meaningfully/validly experiencing and engaging with global issues. In other words, globalisation itself becomes appropriated or rendered manageable by the national; and citizenship education ensures that the agents of this project are properly trained for the task.

A similar sort of nation-centrism can also be seen in some 'inclusive' models proposed by academics. One such model distinguishes between a 'fixed citizenship' and a 'flexible citizenship' (see Morris et al. 2002, 187). The former is geared towards pupils' national life whilst the latter is meant to prepare them for future mobility and migration. Not only does this model take for granted the nation-state as the basic unit of geo-political division, it sees the (rest of the) world as a potential site for investment and other opportunities and assumes that, as adults, national citizens will want to move around the globe to take advantage of those opportunities. However, academics have also posited ideas which are indeed useful steps towards inclusive, multi-levelled models of citizenship. Banks (2004), for example, has emphasised the importance of cultivating individuals' own attachments to their cultural, 
national and global communities, Whilst Osler (2010) has called for nation-states to become reconceptualised as 'cosmopolitan' so that citizens' identities can be more flexible and shift more easily between various levels/dimensions of living. What I will propose below can be seen as picking up on and complicating these ideas. Their potential notwithstanding, I would contend that they do not take questions of identity far enough. Furthermore, as Law $(2011,8)$ points out, they take the stability of the nation-state for granted along with its willing commitment to multiculturalism/cosmopolitanism. But these assumptions are problematic: the socio-political landscape of countries is constantly changing; and commitment to multiuculturalism is a political choice - one which has increasingly fallen out of favour with Western governments in recent years.

Still another framework has been proposed by Law (2011) based on his research in China. Law advances a 'multileveled-multidimensional' citizenship model with four dimensions: global, national, local, and personal-social. ${ }^{8}$ For Law, it is important to remember that these dimensions can interact and intersect. They also cover a range of issues which can go beyond civics to include economic, political, environmental and cultural arenas. Furthermore, they can be tied to the past, present or future; and individuals' awareness of, loyalty to and participation in each may vary in extent. As such, the aim of citizenship education is to ensure that students are adequately taught to function in these four dimensions. A major advantage that Law's model has is that unlike those of Banks and Osler it does not assume domestic stability. In fact, Law emphasises that since the nineteenth century, China's social construction of citizenship and citizenship education have developed in fairly unstable circumstances, for example due to drastic differences in the national leaders' choice of state orthodoxy and leadership priorities $(2011,12)$. The Chinese context also shows that students' mere awareness of global issues does not necessarily help them to develop a sense of global citizenship. Law uses Hong Kong and Shanghai as cases to show that different local strategies develop and promote different domains of citizenship and citizenship education within the same national and international context. Multileveledmultidimensional citizenship and citizenship education, then, are about recognising the fact that young people can (and often do) have multi-tiered belongings and identifications simultaneously. It is thus possible for them to integrate local identities with global ones, or not, whilst also developing a critical patriotism (ibid., 208). For Law, states, local governments and schools are the three main shapers and promoters of citizenship education.

\footnotetext{
${ }^{8}$ For a variant of this model, see Kubow et al. (2000).
} 
Their job, therefore, must be to continually re-invent the subject and its pedagogies so that it allows for the sort of iterative dynamism which exists in young people's identities.

\section{The importance of identity for Citizenship Education}

Law's model is immensely useful and timely. However, emphasising multi-dimensional identities and belongings is inadequate without examining more deeply the processes of identity and how they might relate to citizenship and citizenship education in the late-modern world. What I am suggesting in light of my research findings is that the nationalistic approach to citizenship education is producing in young people the perception of a distinction between citizenship as a particular socio-political category and their own everyday subjectivities, which play out across multiple experiential dimensions. Yet the civic and political socialisation which citizenship education aims to achieve is to a large degree dependent upon and entwined with those everyday subjectivities. For instance, our choice and modality of political participation as well as how we interact with others are intricately tied to our intimate sense of self - the personal is political, as we have often heard from feminists. The perception is therefore a false one. Thus, it stands to reason that citizenship education must begin to develop a more sophisticated understanding of the complexities of the identities of diverse citizens today and provide young people with the reflexive tools to do the same.

In pursuit of this development, two areas seem to me to stand out: 1) the formation and performance of diverse selves; and 2) how these selves come to interact with and value others. I will examine each in turn. A useful insight into how identity is linked to performance can be found in the concept of mimesis. Marcus (1995) argues that a subject need not be the locus in which his/her subjectivity has been forged. That is, an individual's current self can have been 'authored' (and authorized) by agents and processes which are spatially and temporally distanced from the individual. Marcus uses the example of wealthy eccentrics whose only sense of self-awareness is that their selves have been produced by multiple agencies elsewhere. He defines the mimetic self as a 'thoroughly performative, sensorial, and unself-conscious response to the social conditions that define one's selfhood conditions that involve hidden or only partially understood parallel worlds of agency' (Marcus 1995, 52). Thus, a subject's agency partly consists in performing a sort of imitation of a self the social conditions of whose production he/she has had little or no control over.

In my previous work on the Iranian diaspora, I have used this idea to develop the concept of 'vague self' to denote young identities, discourses and behaviours which rely and 
draw upon certain historical, social and political events of which the young diasporans in question had very little knowledge and understanding (Gholami 2015, 119). Rather, they perceived a vague but idealised self (or self-image) which informed and authorised their subjectivity, and which they mimetically (re)performed. Interestingly, however, every performance was ultimately unique because of the distinctive circumstances in which it played out. At present, the English national curriculum for citizenship does very little to account for the fact that young people's assertions of identity are often (re)performances of ideas and ideals of selfhood which have been shaped by highly discontinuous, even contradictory social, cultural and political realities across multiple times and spaces. This is all the more true in globalised, multicultural societies such as Britain. Let us not forget that the young Iranians I studied were for all intents and purposes British citizens - born and raised in Britain; held British passports; identified as British; yet engaged in certain behaviours, discourses and aesthetics which would not have existed without, say, the occurrence of Iran's 1979 Islamic Revolution (an event which long preceded their dates of birth and of which they had very little, if any, knowledge). It is hard to see how the present curriculum could engage these unique but very real and meaningful subjectivities.

In addition to acknowledging the complex formation and performance of identities, citizenship education should also provide tools/skills for reflexivity so that teachers and pupils alike can work with the fact that various histories and places are operative in/through them at any given moment. One idea could be to invite the 'excavation' and critical discussion of those histories and places, with the understanding, however, that these activities are themselves acts of interpretation. Furthermore, all of this must be done with direct reference to the social, political and legal facets of the citizenship concept. That is to say, the very clear links between individual identity and civic/political life should be foregrounded and explored. This will allow young citizens to map their own 'citizenship journeys' - to think about and manage their citizenship in a way which engages rather than alienates them. This is quite removed, and far more useful, than current citizenship education, which is essentially about memorising a set of 'facts' (e.g. rights and duties) or 'respecting' a set of stereotypes, both of which assume the supremacy of a national government representing an ethnic/religious/cultural majority.

The other important issue here is relating to and interacting with other people. I would argue that the present approach to citizenship and citizenship education is based too much on the idea that individuals live wholly discrete lives which may interact with and thus impact upon one another. Yet at least since Max Weber, sociologists have talked about how 
individuals imbue the world with meaning and create their social environment. I think this idea needs to be taken further in the context of citizenship education. The time has come for citizenship education to account much more readily for individuals' creative power in relation to how people interact with each other. That is, who we believe another person to be is largely an act of construction on our part - we are complicit in creating his/her 'otherness'. Thus, it is not the case that an 'other' is out there, completely discretely, for us to like/dislike/tolerate/reject; rather, the particularities of our self-experience coalesce at various spatio-temporal junctures to imbue the world (and the people in it) with specific meanings, thus creating otherness (and sameness). It is only then that we attribute value to others.

These ideas offer some potentially interesting - if a little unconventional implications for citizenship education which become concretised if we approach them through Simon Frith's (1996) work on the consumption of music and how it links with identity and aesthetic judgement. Frith has argued that after production, music acquires a life of its own as 'experience' which, when consumed, becomes constitutive of individual and collective identities. Thus, Frith is not concerned with how a piece of music or a performance reflects a group of people but how it produces them: 'how it creates and constructs an experience - a musical experience, an aesthetic experience - that we can only make sense of by taking on a subjective and collective identity' (Frith 1996, 109, original emphasis). Frith argues that when we listen to and experience music we are in fact experiencing our self-in-process. Given that melodies and rhythms are absorbed directly into our bodies and personal lives, music is an individualising art form. But it also draws us into 'emotional alliances' with the performers and with other fans. Therefore, we are also part of a collective experience. The consumption of music, then, has the capacity to offer us the experience of different/other identities and place us in difference cultural narratives and modes of social interaction.

Importantly, Frith also emphasises a link between aesthetics and ethics. The subjective-ness of musical experience undermines the dichotomy between 'serious/high' and 'popular/low' music (ibid., 119). The rejection of this dichotomy means that the aesthetic value of all forms of music is high (or low), depending on who is listening. Frith contends that the choices people make about what sort of music should be made, sold and performed imply the exercising of judgement. In other words, people make and listen to music because it 'sounds good', thus distancing 'good' or 'authentic' music from the commercial forces which have organised it. As such, the source of value is rooted in the consuming person or community, and the aesthetic judgement people make is spuriously projected back onto the 
music making and listening processes. Thus, 'good music must be music made and appreciated by good people' (Frith ibid., 121). That is, what sounds good comes to signify and be experienced as what is good (ibid., 124) - the opposite is also true, of course.

At the risk of being too unorthodox, I think Frith's ideas can be usefully applied to a citizenship education which is serious about engaging more deeply with young people and offering them sophisticated tools for understanding and reflection. Above, I discussed the complex spatio-temporal and performative dimensions of identities. If we further think about Foucault's (1988) ideas on self-stylisation and technologies of the self as well as how this work has been extended through Butler's (1990) notion of performativity, a picture begins to emerge of what I think of as 'the art of self-making'. This denotes an ongoing process in which the subject is constantly reflecting on the effects of time, space and other social and physical factors to negotiate, 'curate' and (re)perform multiple identities. In this context, it is not unreasonable to conceive of a given self-performance like Frith conceives of music - an experience which the 'producer' has little control or claim over; which is diffuse in the social world and can be consumed by others as an experience. In turn, this consumption becomes a highly significant and creative act through which the consuming person assigns value to and thus co-constructs the 'performer'. I think it is vital for citizenship education to proceed from the premise that how we interact with, react to and feel about others is to a great extent (if not entirely) due to meanings, interpretations and narratives that we ourselves have created (rather than 'what they did/who they are'). Furthermore, because the experience is foremost of one's own collective and individual self-in-process, the act of consumption says a great deal about the subject positions which matter most to the consuming person. It is therefore an immensely valuable reflective tool. In citizenship education lessons, young people could reflectively interpret and discuss their experiences of each other's self-performances much like they do with other forms of art. These discussions could then be connected quite meaningfully to the various strands of the citizenship education curriculum - not only to learn but also to critique them. This opens up the crucial path to developing 'pedagogies of interpretation' which would facilitate more flexible, reflexive and dialogic interactions in place of rigid judgements and problematic value systems around notions of 'respect' and 'tolerance'. 


\section{Conclusion}

At its core, this paper has advanced the argument that a myopic and exclusivist approach to citizenship in the English National Curriculum has produced an experiential chasm between the social, political and legal aspects of citizenship and the everyday living of diverse young British citizens. It has shown that many of those who have received statutory citizenship education have graduated with a sense of indifference and disengagement vis-à-vis civic and civil matters. Yet, important though they are, the political and legal dimensions of citizenship are meaningless unless they can properly engage the very lives which engender social, political and legal arenas. As we have also seen, however, banging on about respect, tolerance, diversity, globalisation, and so forth, and modifying the curriculum have not been very successful in bringing about meaningful engagement. And there are two reasons for this: firstly, those concepts - as with the rest of the citizenship curriculum - are defined primarily with reference to national(ist) ideology. Thus, we have hierarchies, value systems, enemies/friends, and so on, before we have even begun to talk about what, say, 'respect' could possibly mean. Similarly, national governments take a very particular stance towards globalisation, probably the most important force of our time. Rather than being interested in harnessing its potentials for truly global and egalitarian models of citizenship, governments either feel threatened by it - in which case they clam up and take more right-wing positions or they approach it as a sort of internationalisation which promises huge benefits for the citizens of powerful countries (and not much for everyone else). The second reason is that human lives are complex. Subjects (who live everyday lives as citizens) are shaped, sometimes curated, at the intersection of multiple spatial, temporal, experiential and sociocultural realities. It is unreasonable, as others too have suggested, to assume that people will/can give prominence to the national dimension over all the others; it is even more unreasonable - not to mention violent - to expect them to, as the British government and the English curriculum for citizenship education do.

In this context, I explored how the links between individual identity and citizenship can be foregrounded to allow young people to invest in the idea of citizenship beyond superficial levels. I emphasised 'the art of self-making' to propose a deeply reflexive approach to teaching/learning about citizenship which accounts for the late-modern complexities of selfhood and ties them explicitly to the citizenship concept. This model underscores the performative dimension of identity, whilst making the unorthodox argument that 'relating-to-others' can be reconceptualised as consuming someone's self-performance, 
much like we consume and pass aesthetic judgement on a musical experience. The consumer is deeply implicated in his/her act of consumption and not only is complicit in creating 'the experience' (of otherness), but is also afforded a good opportunity to reflect on his/her own subjectivity. I believe that by debating and implementing these ideas we can develop a model of citizenship education which is genuinely interested in better understanding and addressing the diverse and complex human beings who are/become citizens and facilitates in them deep reflexivity, interpretation, dialogue and openness based on a sloid commitment to conviviality. 


\section{Acknowledgements}

I would like to thank Mr Prakash Daswani and his staff at Cultural Co-operation for supporting the project from which this paper derives intellectually and logistically. They will no doubt continue to play an important role in the provision of citizenship education London and beyond. I also express my gratitude to Prof. Richard Fardon at SOAS, University of London, whose guidance throughout the project was indispensable. Last but not least, I wish to thank all the young people who gave me their time and participated in the study. 


\section{References}

Agamben, G. 1998. Homo Sacer: Sovereign Power and Bare Life. Stanford: Stanford Universiy Press.

Appadurai, A. 1996. Modernity at Large. Minnesota University Press.

Banks, J. 2004. "Democratic Citizenship Education in Multicultural Societies," in Banks, J. ed. Diversity and Citizenship Education: Global Perspectives. San Francisco: Jossey-Bass Publishers.

Butler, J. 1990. Gender Trouble: Feminism and the Subversion of Identity. New York: Routledge.

Carens, J.H. 1987. "Aliens and Citizens, the case of open borders," The Review of Politics. 49 (2): 251273.

Castles, S. 2009. "World Population Movements, Diversity, and Education," in Banks, J. ed. The Routledge International Companion to Multicultural Education. New York: Routledge.

Castles, S. and Davidson, A. 2000. Citizenship and Migration: Globalization and the Politics of Belonging. Routledge.

Cohen, A. 1993. Masquerade Politics: Explorations in the Structure of Urban Cultural Movements. Oxford: Berg

Delanty, G. 2001. "Cosmopolitanism and Violence: The Limits of Global Civil Society," The European Journal of Social Theory 4 (1): 41-52.

Department for Education. 2013. "Citizenship: Programmes of Study for Key Stages 3 and 4", London: DfE.

Department for Education. 2011a. "The Framework for the National Curriculum: A report by the Expert Panel for the National Curriculum review", London: DfE.

Department for Education. 2011b. "Review of the National Curriculum in England: Report on Subject Breadth in International Jurisdictions (DFE-RR178a)", London: DfE.

Dimitrov, G. and Boyadjieva, P. 2009 "Citizenship Education as an Instrument for Strengthening the State's Supremacy: An Apparent Paradox?" Citizenship Studies 13 (2): 153-169.

Fernando, M. 2009. "Exceptional Citizens: Secular Muslim Women and the Politics of Difference in France", Social Anthropology, 17(4): 379-92.

Fong, V. 2006. "Chinese Youth between the Margins of China and the First World," in Fong, V. and Murphy, R. eds. Chinese Citizenship: Views from the Margins. London: Routledge.

Foucault, M. 1988. “Technologies of the Self” in Martin, L. M. et al. (Eds.) Technologies of the Self. Amherst: University of Massachusetts Press. 
Frith, S. 1996. "Music and Identity", in Hall, S. and Du Gay, P. (Eds.) Questions of Cultural Identity. Sage Publications.

Gholami, R. 2015. Secularism and Identity: Non-Islamiosity in the Iranian Diaspora. Surrey, UK; Burlington, VT, USA: Ashgate.

Gilroy, P. 1993. The Black Atlantic: Modernity and Double Consciousness. London and New York: Verso.

Hall, S. 1992. "The Question of Cultural Identity," In Hall, S. Held, D. and McGrew, T. eds. Modernity and Its Futures: Understanding Modern Societies, Polity Press.

Hall, S. 1991. "The Local and the Global: Globalization and Ethnicity", in King, A. D. ed. Culture, Globalization and the World System. New York: Macmillan.

Hart, S. 2009. 'The 'problem' with youth: young people, citizenship and the Community', Citizenship Studies, 13 (6): 641-657.

Holton, R. J. 2011. Globalization and the Nation State. Basingstoke and New York: Palgrave Macmillan.

Jameson, F. 1991. Postmodernism, or the Cultural Logic of Late Capitalism. London: Verso.

Keating, A., Benton, T. and Kerr, D. 2011. "Tracing the trends and transitions in young people's citizenship practices: what are the implications for researching citizenship and citizenship education?" Educational Research, 53 (2): 223-235.

Keating, A., Kerr, D., Benton, T., Mundy, E. and Lopes, J. 2010, "Citizenship education in England 2001-2010: young people's practices and prospects for the future: the eighth and final report from the Citizenship Education Longitudinal Study (CELS) (DFE RB059)" London: National Foundation for Educational Research/Department for Education.

Kennedy, K. J. 2010. "Neo-Statism and Post-Globalization as Contexts for New Times," in Ried, A., Gill, J. and Sears A. eds. Globalization, the Nation-State and the Citizen: Dilemmas and Directions for Civics and Citizenship Education. London: Routledge.

Kubow, P. et al. 2000. "Multidimensional Citizenship: Educational Policy for the 21st Century," in Cogan, J. and Derricott, R. eds. Citizenship for the 21st Century: An International Perspective on Education. London: Kogan-Page.

Kringelbach, H. N. and Skinner, J. 2012. "The Movement of Dancing Cultures" in Kringelbach and Skinner (Eds.) Dancing Cultures: Globalization, Tourism and Identity in the Anthropology of Dance. New York and Oxford: Berghahn Books. pp. 1-29

Law, W. W. 2011. Citizenship and Citizenship Education in a Global Age: Politics, Policies and Practices in China. New York: Peter Lang

Levinson, B. 2011. "Toward and Anthropology of (Democratic) Citizenship Education," in Levinson, B and Pollock, M. eds. A Companion to the Anthropology of Education. Blackwell, pp. 279-299. 
Marcus, G. E. 1995. "On Eccentricity," in Battaglia D. (ed.) Rhetorics of Self-Making. Berkeley and Los Angeles: University of California Press.

Maylor, U., Read, B., Mendick, H., Ross, A. and Rollock, N. 2006. "Diversity and Citizenship in the Curriculum: Research Review." London: DfES.

Morris, P., Cogan, J. and Liu, M. 2002. "A Comparative Overview: Civic Education across the Six Societies," in Cogan, J., Morris, P. and Print, M. eds. Civic Education in the AsiaPacific Region: Case Studies across Six Societies. New York and London: RoutledgeFalmer.

Ong, A. 1999. Flexible Citizenship: the Cultural Logics of Transnationality. Duke University Press.

Osler, A. 2015. "The Stories We Tell: Exploring Narrative in Education for Justice and Equality in Multicultural Contexts" Multicultural Education Review 7 (1-2): 12-25

Osler, A. 2010. "Citizenship and the Nation-State: Affinity, Identity and Belonging," in Reid, A. et al. eds. Globalization, the Nation-State and the Citizen: Dilemmas and Directions for Civics and Citizenship Education. London: Routledge.

Qualifications and Curriculum Authority. 1998. "Education for Citizenship and the Teaching of Democracy is Schools", London: QCA.

Schinkel, W. 2010. “The Virtualization of Citizenship,” Critical Sociology, 36 (2): 235-283. 